
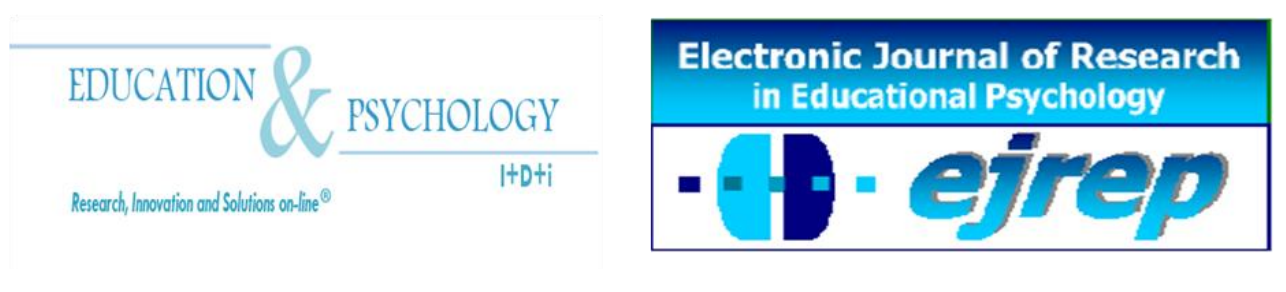

Editorial EOS

\title{
Examining the Student-Teacher Relationship Scale in the Italian Context: A Factorial Validity Study
}

\section{Michela Fraire, Claudio Longobardi, Laura Elvira Prino, Erica Sclavo, Michele Settanni}

Department of Psychology, University of Turin

\section{Italy}

Correspondence: Claudio Longobardi. Department of Psychology, University of Turin, Via Po 14, 10123, Torino, Italy. E-mail: claudio.longobardi@unito.it

(C) Education \& Psychology I+D+i and Editorial EOS (Spain) 


\section{Abstract}

Introduction. A growing body of literature suggests that the quality of teacher-child relationships is a determining factor in children's competence in social-emotional, behavioral functioning, and academic skills. Most of the research on student-teacher relationships has relied on these relationship perceptions. A well-known instrument to assess these perceptions is the Student-Teacher Relationship Scale (STRS). Up to now, only a few studies have focused on the cross-cultural validity of the STRS. To date, only one study have examined the factorial confirmatory validity in the United States. In the European context, other investigators have examined and confirmed the applicability of the STRS in Spain, Greece and in the Netherlands.

Method.The purpose of this study is to examine the factorial structure validity of the StudentTeacher Relationship Scale) in the Italian schooling system on a sample consisting of 1256 children, ranging in age from 3 to 9 years, and 210 teachers.

Results. The parameter estimates obtained from confirmatory factor analysis identified items with low factor loadings, suggesting that content revision is required for these items on the original version of the STRS, which comprises 28 items. Exploratory factor analysis showed that the deletion of 6 items from the scale offered a good model fit, suggesting that the remaining 22 items reliably and validly measure the constructs for the whole sample: closeness $(\alpha=.85)$, conflict $(\alpha=.92)$, and dependency $(\alpha=.69)$.

Discussion and Conclusion. These findings might be attributed to the difference between Italian teachers' cultural backgrounds and the original cultural context of the STRS. This study provides implications for construct validity research and substantive research using the STRS, given that the STRS is used extensively in intervention and research in early childhood education. On the basis of the obtained results, the questionnaire seems to be a adequate instrument to study the teacher-pupil relationship, both as a monitoring scale of a given relationship and as a way to help teachers achieve more awareness of their educational skills.

Keywords: teacher-child relationship, confirmatory factor analysis, STRS, school psychology, educational psychology 


\section{La Escala "Student-Teacher Relationship Scale" dentro del contexto italiano: un estudio de validez factorial}

\section{Resumen}

Introducción . Un número creciente de estudios sugiere que la calidad de las relaciones entre maestros y niños es un factor determinante en la competencia de los niños, en el desarrollo social emocional, en el funcionamiento de la conducta y en las habilidades académicas . La mayor parte de la investigación sobre las relaciones alumno-maestro se ha basado en estas percepciones de la relación. Un instrumento utilizado para evaluar estas percepciones es la Student-Teacher Relationship Scale (STRS). Hasta ahora, sólo unos pocos estudios se han centrado en la validez transcultural de la STRS. De momento, sólo un estudio ha examinado la validez factorial confirmatoria en los Estados Unidos. En el contexto europeo, otros investigadores han examinado y confirmado la aplicabilidad de la STRS en España, Grecia y en los Países Bajos.

Método. El objetivo de este estudio es analizar la validez factorial de la Escala de relación profesoralumno (STRS) en un contexto escolar italiano formado por 1256 niños, con una edad comprendida entre los 3 y los 9 años y 210 profesores.

Resultados. La estimación de las variables obtenidas a través del análisis factorial confirmatorio identifica ítems con cargas factoriales bajas, lo cual sugiere una revisión del contenido de dichos ítems en la versión original del STRS, que abarca 28 ítems. El análisis factorial evidencia que la eliminación de 6 ítems de la escala encaja bien con el modelo, lo cual indica que los restantes 22 ítems miden con validez y fiabilidad los constructos de la muestra entera: cercanía $(\alpha=.85)$, conflicto $(\alpha=.92)$ y dependencia $(\alpha=.69)$.

Discusión y Conclusiones. Estas conclusiones se atribuirían a la diferencia entre los conocimientos culturales de los profesores italianos y el contexto cultural originario de la STRS. Este estudio otorga nuevos elementos para la investigación de la validez de constructo y la investigación sustantiva utilizando la STRS, dado que la STRS se utiliza extensivamente en intervención e investigación sobre educación infantil. Según los resultados obtenidos, el cuestionario resulta ser un instrumento válido para estudiar la relación profesor-alumno, ya sea como escala de monitorización de una relación dada, ya sea como método para ayudar a los profesores a conseguir una mayor conciencia de sus habilidades educativas.

Palabras Clave: relación profesor-alumno, análisis factorial confirmatorio, STRS, psicología educativa. 


\section{Introduction}

Amidon and Hunter (1967), as well as Klauer (1985) some twenty years later, considered teaching to be an interactive and interpersonal process, and this process seems to influence classroom experience and emotional development. Giving preeminence to the teacherchild relationship as early as possible is a crucial objective, as current estimates indicate that well over $75 \%$ of young children attend center-based care for some portion of the day, and the accreditation standards directed at preschool programs recognize the importance of ensuring the quality of children's relationships with their teachers (Barnett \& Yarosz, 2004). Efforts to ensure functional teacher-child relationships must begin as early as possible, ideally within the preschool years, as children's attainment of a certain "readiness" by the beginning of kindergarten serves as an important and reliable predictor of children's long-term schooling proficiency (Snow, 2006). A growing body of literature suggests that the quality of teacher-child relationships is a determining factor in children's competence in social-emotional, behavioral functioning, and academic skills (Baker, 2006; Birch \& Ladd, 1997; Burchinal, PeisnerFeinberg, Pianta, \& Howes, 2002; Hamre \& Pianta, 2001; Hughes, Luo, Kwok, \& Loyd, 2008; Murray, Murray, \& Waas, 2008; O’Connor \& McCartney, 2007). Although it is evident from the literature that the quality of children's relational history (e.g., their attachment relationship with caregivers as well as previous attachment-like relationships with teachers) offers special explanatory value in predicting the quality of teacher-child relationships (O'Connor \& McCartney, 2006), additional factors also explain significant amounts of variance along these lines. These include, for instance, the length of the school day and time spent in the classroom, school relational climate and teacher's instructional practices (Mantzicopoulos, 2005), teacher's years of experience (Stuhlman \& Pianta, 2002), teacher's racial background and teacher's attachment history (Kesner, 2000), and level of educational attainment of children's parents (Ladd, Birch, \& Buhs, 1999).

\section{Theoretical Framework in Teacher-Child Relationships}

Relationships with teachers have been studied from the perspective of the Attachment Theory, in which teachers, especially in early childhood, are seen as "alternative caregivers" (Howes, 1999) and as extensions of the parent-child relationship (Davis, 2003). Children who feel emotionally secure with their teachers can communicate effectively and are better able to devote their attention to learning (Pianta, 1999). Since teacher-child interactions represent a 
bidirectional, transactional process between individuals, it is important to recognize and understand what each individual may contribute to these interactions, as well as how other contextual factors may serve as facilitators or impediments. Pianta and Walsh (1996) developed the Contextual Systems Model (CSM), designed to explain the experiences of children in school, which is a good example of an ecological-contextual model of development. To understand these multilevel influences on the quality of interactions, we draw from literature that examines proximal and distal factors that predict the quality of these interactions (Bronfenbrenner, 1977). Proximal factors are all those features that relate to the individuality of the teacher and the pupil. They include biological factors, such as gender, as well as attitudes and predispositions, such as temperament, sensitivity, and beliefs (Myers \& Pianta, 2008). More distal influences include the family, classroom, and sociocultural contexts. According to these models, the influence of a factor in one system cannot be evaluated without considering factors in the other systems (Bronfenbrenner, 1977; Pianta \& Walsh, 1996). Also, the concept of ecological transition seems to be central here, transitions that happen every time the subjects come into contact with new environments, roles, and relationships. Preschool represents a relevant ecological transition for all the children that access this level of schooling; therefore, it should not be considered an isolated system but an integral part of that wider system of relationships that exists in all environmental contexts. Therefore, an educational model oriented toward a conception of the ecological development of the individual cannot but consider the varied forms of interactions and interchange that the child experiences inside and outside the school (Bronfenbrenner \& Morris, 2006; Hamre \& Pianta, 2010; Tudge, Mokrova, Hatfield, \& Karnik, 2009).

In addition, current theoretical orientations emphasize the need to view school readiness through a developmental systemic perspective that "highlights the central role of social relationships" (Mashburn, Hamre, Bowner, \& Pianta, 2006, p. 152). Therefore, teacher-child relationships should be measured to examine their nature and make valid explanations regarding their influence on children's development.

Also, the regulations that govern the Italian educational system underline the value of the teacher-pupil relationship. "Nuovi Orientamenti" ["New Orientations"] (Decreto Ministeriale, June $3^{\text {rd }} 1991$ ), concerning preschool (age 3-5), underlines how adult relational competencies have a fundamental value in establishing a functional relationship that takes heed of the affective, cognitive, and socializing elements of educational practice. In the 
"Indicazioni Nazionali per il Curriculo" ["Curricular National Recommendations"] (Ministry of Public Education, 2007) for primary school (age 6-10), it was noted that the educational environment is an interdependently interrelated community permeated with emotional elements tied to growth and learning processes.

\section{Teacher-Child Relationship Perceptions}

Teacher-child relationships are viewed as micro-systems that consist of multiple interrelated characteristics and perceptions that both child and teacher have about the contingent interaction (Pianta, Hamre, \& Stuhlman, 2003). Rather than neutral recordings of self-other interactions, these internal perceptions are personal representations hued by feelings, evaluations, beliefs, and expectations. Still, they have important consequences for actual teacherchild interactions because they are psychologically real and influence the behaviors of each party (Stuhlman \& Pianta, 2001). Therefore, teachers bring various practices, perceptions, and beliefs to the classroom that can influence interactions with students. Indeed, teacher characteristics account for more variance than preschool children's temperament characteristics in teacher-child conflict and dependency (Rudasill, Rimm-Kaufman, Justice, \& Pence 2006).

Most of the research on student-teacher relationships has relied on these relationship perceptions. A well-known instrument to assess these perceptions is the Student-Teacher Relationship Scale (STRS; Pianta, 2001). The teacher-pupil relationship is constructed on elements of closeness, conflict, and dependency, which all define the way in which both the teacher and the child behave with each other (Birch \& Ladd, 1997; Pianta, 1994). These dimensions are consistent across child age, ethnicity, and socioeconomic status (Saft \& Pianta, 2001); are stable from kindergarten to second grade (Birch \& Ladd, 1997); and map conceptually onto children's perceptions of relationships with teachers (Lynch \& Cicchetti, 1992) as well as constructs such as control and warmth observed in parent-child interactions (Pianta, Nimetz, \& Bennett, 1997).

\section{Teacher-Child Relationship Quality: Multidimensional Construct}

As described by Birch and Ladd (1997), closeness is a warm affective relationship with a teacher that may promote positive attitudes toward school, open communication, involvement, and engagement. It encompasses how comfortable children seem to be in ap- 
proaching the teacher, talking about their feelings and experiences, and using the teacher as a source of support and comfort when upset (e.g., Pianta et al., 2003).

A close relationship with the teacher may allow children to openly express their feelings and concerns that elicit appropriate guidance from teachers and enhance effective instructional interactions (Burchinal, Cryer, Clifford, \& Howes, 2002; Burchinal et al. 2008; Burchinal, Peisner-Feinberg, Pianta, \& Howes, 2002; Pianta, 1999). From close relationships with teachers, children may derive emotional support and security, which, in turn, may enhance positive behaviors and exclude more negative behaviors (such as aggression) in the classroom and with peers outside (Howes, 2000; Ladd et al., 1999). Greater closeness may encourage children's learning and school performance and is associated with more positive feelings about school (e.g., Birch \& Ladd, 1997), fewer behavioral problems, more behavioral competencies and social skills (e.g., Buyse, Verschueren, Doumen, Van Damme, \& Maes, 2008; Hughes, Cavell, \& Jackson, 1999; Pianta \& Stuhlman, 2004; Silver, Measelle, Armstrong, \& Essex, 2005), and higher academic achievement (e.g., Birch \& Ladd, 1997).

Furthermore, positive relationships with teachers can protect against the poor school performance associated with an unsupportive home environment (Cicchetti \& Lynch, 1993). In a sample of maltreated and non-maltreated children, Lynch and Cicchetti (1992) concluded that maltreated children may express a greater desire for closeness to non-parental adults compared to non-maltreated children.

Conflict measures the degree of negativity, discordant interactions, and lack of rapport between a teacher and a child, which might function as stressors for children in the class. As a potential stressor in the school environment, teacher-child conflict may be emotionally upsetting to young children, yielding negative behaviors. It has been established that, during the years of elementary school, highly conflictual relationships with a teacher can cause serious behavioral issues, especially in the realm of social skills and interactions (Doumen, Versehuerer, Buyse, Germeiis, Luyckx, \& Soenens, 2008; Mantzicopoulos, 2005; Pianta, Mashburn, Downer, Hamre, \& Justice, 2008). They can also inhibit good academic performance (Di Lalla \& Wright-Phillips, 2004) and positive attitudes toward school work (Hamre \& Pianta, 2001; Hamre \& Pianta, 2007) and increase the risk of the child's missing school on a regular basis (Birch \& Ladd, 1997). A high level of conflict has been linked more strongly than the level of teacher-child closeness to school outcomes for children in elementary school 
(Baker, 2006). For example, Baker (2006) found that, compared to close relationships, conflictual teacher-child relationships account for more variance in academic achievement and positive work behaviors (e.g., adjustment to the norms, routines, and expectations of the classroom) for children in elementary school.

Dependency measures children's possessive, clingy, and over-reliant behaviors. A child who is overly dependent on the teacher tends to be hesitant in his or her explorations of the classroom/school environment. Children's clingy behaviors may hinder social interactions with peers and foster feelings of loneliness and negative attitudes toward school (Birch \& Ladd, 1997). The dependency measure has not been widely used in teacher-child relationship research in the past decade (e.g., Jerome, Hamre, \& Pianta, 2009).

\section{Measuring Teacher-Child Relationships}

For the most part, studies of teacher-child relationships have used measures derived from Attachment Theory or adapted from child-parent attachment measures to describe and assess non-parental relationships. These include observational measures of dyadic interaction, the Strange Situation Procedure (SSP; Ainsworth, Blehar, Waters, \& Wall, 1978) and the Attachment Q-Sort (AQS; Waters \& Dean, 1985), and teacher-rated measures derived from the Student-Teacher Relationship Scale (STRS) questionnaire (Pianta, 1994; Pianta \& Steinberg, 1992). However, to our knowledge, the SSP and AQS have not been applied to school environments or student-teacher relationships. Once children enter school, researchers have tended to measure relationship quality using the STRS, which asks teachers to rate the degree to which conflict, dependency, warmth, and open communication characterize their interactions with and feelings about a child.

The 28-item version of the STRS, rated on a 5-point Likert-type scale, was refined based on principal component analysis procedures (Pianta \& Steinberg, 1992; Saft, 1994; Steinberg, 1993), and scores on the STRS have been associated with measures of children's behaviors and social adjustment and academic performance (e.g., Baker, 2006; Burchinal, Cryer, Clifford, \& Howes, 2002; Decker, Dona, \& Christenson, 2007; Ewing \& Taylor, 2009; Hamre \& Pianta, 2001; Mashburn, Downer, Hamre, Justice, \& Pianta, 2010; Murray et al., 2008; O'Connor \& McCartney, 2007). Previous validity studies have reported that a threefactor solution accounted for $45.5 \%$ (Saft, 1994) to $51.5 \%$ (Steinberg, 1993) of the variance. 
Consequently, the STRS consists of three distinct aspects of teacher-child relationships (closeness, conflict, and dependency), and good relationships are defined by low levels of conflict and over-dependency and high levels of closeness.

Previous validity studies have reported internal consistency, measured by Cronbach's alpha coefficients, ranging from .91 to .93 for the conflict scale, .85 to .87 for the closeness scale, and .64 to .68 for the dependency scale. Test-retest reliability, according to Pearson correlation coefficients based on a 4-week interval, are reported to be .89 for the total scale, .92 for conflict, .88 for closeness, and .76 for dependency. The studies mentioned above seem to provide support for the STRS as a potentially reliable and valid measure of teachers' perceptions of teacher-child relationships. Indeed, research on the associations of the STRS and school outcomes provide evidence for the external aspect of construct validity (criterionrelated validity in terms of the traditional conception of validity), which refers to the degree to which the relationships of test or scale scores with other measures reflect the expected relations in the theory of the construct being assessed (Loevinger, 1957).

Up to now, only a few studies have focused on the previous versions of the STRS (Pianta \& Steinberg, 1992; Saft, 1994; Steinberg, 1993). To date, only Webb and NeuharthPritchett (2011) have examined the factorial confirmatory validity of the current 28-item version of the STRS in the United States and concluded that a 26 -item version was a reliable and valid measure of the teacher-child relationship. Similarly, other European investigators, such as Gregoriadis and Tsigilis (2008; Tsigilis \& Gregoriadis, 2008) have examined the applicability of the STRS (the 28-item version and the short form) in the Greek educational setting with exploratory factor analysis (EFA) and arrived at the same conclusions as Webb and Neuharth-Pritchett (2011). In the Netherlands, Koomen, Verschueren, van Schooten, Jak, and Pianta (2012) also examined the applicability of the STRS using confirmatory factor analysis (CFA). Their results confirmed the applicability of the instrument in the Dutch schooling system with the only difference of extending the age up to 12 years old as opposed to the original range.

\section{Objective}

On the basis of the previously cited studies, which opened the way to the use of the STRS in Europe, the purpose of the current study, therefore, is to evaluate the factorial validity of the 28-item version of the STRS in the Italian schooling system by examining the postu- 
lated factor structure of the STRS via exploratory factor analysis (EFA) and confirmatory factor analysis (CFA).

\section{Method}

\section{Participants}

The total number of teachers involved in the study was 210 , recruited from 5 different schools. The teacher sample was not sex-balanced (92\% females), reflecting the actual Italian gender distribution of childhood and primary school teachers (Organization for Economic Cooperation and Development [OECD], 2011). The age distribution and the years of experience (see Table 1) of the sample mirrors the characteristics of the population of teachers in the Italian territory (Fondazione Giovanni Agnelli, 2011) (see Table 1). Most of the teachers involved in the study (57\%) had spent more than 15 hours per week in the classroom from which the children were selected; all the teachers had worked with class since the beginning of the school year.

Table 1. Distributions of type of teacher characteristics

\begin{tabular}{llc}
\hline & & Percentage \\
\hline Gender & Female & $91.5 \%$ \\
& Male & $8.5 \%$ \\
\hline Age (years) & 18 to 30 & $3.8 \%$ \\
& 31 to 40 & $24.4 \%$ \\
Teaching experience (years) & 41 to 50 & $42.1 \%$ \\
& More than 50 & $29.8 \%$ \\
\hline Less than 1 & $.9 \%$ \\
& $1-5$ & $7.0 \%$ \\
& $6-10$ & $12.3 \%$ \\
& $11-15$ & $17.1 \%$ \\
& $16-20$ & $16.7 \%$ \\
& $21-25$ & $11.5 \%$ \\
$26-30$ & $14.3 \%$ \\
\hline
\end{tabular}


The final completed questionnaires collected data referring to 1256 children, ranging in age from 3 to $9(M=6.0, S D=1.6)$. With respect to the expected number of questionnaires (6 for each teacher, $N=1260$ ), 4 questionnaires were missing because two teachers sent back only 4 completed questionnaires instead of 6 . The sample was balanced for gender (males = $50.5 \%)$. Forty-four percent $(n=550)$ of the sample attended preschool and $56 \%(n=706)$ the first three years of primary school.

\section{Instruments}

Student Teacher Relationship Scale (STRS; Pianta, 2001). The Student-Teacher Relationship Scale assesses "a teacher's feelings about his or her relationship with a student, the student's interactive behavior with the teacher, and a teacher's beliefs about the student's feelings toward the teacher" (Pianta, 2001, p. 1). This is a self-report instrument consisting of 28 items developed from the Attachment Theory, the Attachment Q-set (Waters \& Deane, 1985), and a review of the literature on teacher-child interactions. It is designed to be used with children ranging in age from 3 to 8 (preschool through $3^{\text {rd }}$ grade; e.g., Birch \& Ladd, 1997, 1998; Howes \& Hamilton, 1992; Howes \& Richie, 1999). Teachers rate the items on a 5-point Likert scale that ranges from 1 (definitely does not apply) to 5 (definitely applies). After a series of validation studies (Pianta, 1999, 2001), the final form of the scale has 3 factors, identified as Conflict (Cronbach's $\alpha=.93$ ), Closeness (Cronbach's $\alpha=.86$ ), and Dependency (Cronbach's $\alpha=.69$ ) subscales. The Conflict Scale comprises 12 items. A high conflict score means "that the teacher struggles with the student, perceives the student as angry or unpredictable, and consequently feels emotionally drained and believes he/she is ineffective" (Pianta, 2001, p. 2). The Closeness Scale is made up of 11 items. A high closeness score indicates "that the relationship is characterized by warmth, and the teacher believes he or she is effective because the student uses the teacher as a source of support" (Pianta, 2001, p. 2). Finally, the Dependency Scale has 5 items, and a high dependency score means that the "teacher perceives a particular student as overly dependent on him/her.... the student reacts strongly to separation from the teacher, requests help when not needed, and consequently the teacher is concerned about the student's overreliance" (Pianta, 2001, p. 2). The STRS has been validated with samples composed of low-income and minority subjects and has also been demonstrated to have predictive and concurrent validity (Koomen et al., 2012; Webb \& NeuharthPritchell, 2011). It has been shown to be related to current and future academic skills and disciplinary infractions (Hamre \& Pianta, 2001), behavioral adjustment and peer relations (Birch \& Ladd, 1998), and risk of retention (Pianta, Steinberg, \& Rollins, 1995). 


\section{Academic achievement and commitment.}

The teachers, in addition to STRS questionnaire, specified the gender and the age of the child and evaluated his/her academic achievement and commitment on a 5-point Likert scale on the basis of the global evaluation given by the class teachers. The teachers were also asked to provide data concerning their own sociodemographic characteristics and teaching experience.

\section{Adaptation to the Italian language.}

We conducted four focus groups with twelve teachers each (45 females, 3 males, average age $41.7, S D=8.5$, range: 28-59). All the group members have worked in either preschools or primary schools. The goal of the first two groups was to rigorously evaluate and study the dimensions that characterize the teacher-child relationship to determine the pertinence of an instrument such as the STRS to the Italian context.

The scale was translated into Italian following the criteria established by Van de Vijver and Hambleton (1996) concerning the adaptation of assessment tools to foreign languages and cultures. Two bilingual people were initially involved into the process of translation from English to Italian. Subsequently, the original questionnaire and the Italian translation were compared by a second pair with the task of identifying any discrepancies between the original language and Italian.

Finally, the last two focus groups verified the readability of the scale items and their applicability to the Italian educational context: no elements worthy of notice emerged. The discussion was focused on the signification nuances of specific terms such as "affectionate relationship" and "to please me".

\section{Procedure}

Five schools were randomly selected, each located in a different area of Italy (northeast, north-west, central, southern, and islands areas) following the typical distribution of most studies conducted by the Italian Institute of National Statistics (ISTAT). A letter along with the application form and an explanation of the project was initially sent to the school directors. After the directors agreed to take part in the project, one teacher was selected from each section of preschool classes and from each of the first three grades of primary school; the teachers then completed the STRS for three males and three females randomly selected from 
the pupils in each class. The instruments were administered in the last two months of the school year to teachers who had worked with the class since the beginning of the school year. To guarantee adequate knowledge of the children, the teachers who participated in the study were selected from among those who spent more time with the children, excluding those who had only a few teaching hours with the classes. In fact, to be recruited for the study, each teacher needed at least 7 teaching hours per week in the class. An envelope was given to each teacher containing 6 STRS questionnaires, each containing 6 modules used to collect data about the students, and one questionnaire requiring personal data about the teacher himself/herself.

\section{Data analysis strategy}

The initial sample was randomly divided into two subsamples, each containing 628 children. Data from the first sample were analyzed by applying exploratory factor analysis (EFA), as done by Pianta (2001) on the American validation sample, to identify possible misbehaving items in the Italian sample. The EFA results allowed us to assess which factors should be retained and which items had to be excluded from the Italian version of the STRS. Then, confirmatory factor analysis (CFA) was conducted to test the adherence of the retained items' factor structure to Pianta's (2001) original factor structure, even after having considered the reciprocal correlations of the resulting subscales. Factor analyses were conducted using Mplus 6.11 (Muthén \& Muthén, 2007). Given the nature of the items (5-point Likert scales) and their skewed distributions, both the EFA and the CFA were conducted using the weighted least squares mean variance-adjusted (WLSMV) estimator, which is to be preferred with ordinal items with skewed distributions (Muthén \& Kaplan, 1985). Afterward, the reliability of the three subscales was computed on the overall sample using Cronbach's Alpha. Finally, to find further evidence for construct validity, we conducted demographic subgroup comparisons based on the overall sample for all three subscales and computed the correlations of the three subscales with academic outcomes and motivation indicators.

\section{Results}

\section{Exploratory Factor Analyses}

Exploratory factor analysis was employed to assess the multidimensional structure of the construct measured by STRS. The EFA was performed using WLSMV estimation and an oblique (Geomin) rotation, with a final sample of $n=628$. The oblique rotation was chosen on 
the basis of the correlations among the three subscales found by Pianta (2001) in his validation study. In the first step, all 28 indicators were retained for the analysis. The number of factors to be retained was determined using a scree plot examination (Cattell, 1966).

\section{Parallel Analysis (PA) and Factor Structure Interpretability}

Parallel analysis (Horn, 1965; O'Connor, 2000) represents a highly accurate method for determining the number of factors (Hoyle \& Duvall, 2004; Russell, 2002). In PA, the number of raw data eigenvalues that exceed random data eigenvalues indicate the number of factors to retain. The PA criteria and the examination of the scree plot suggested that the 3factor solution was appropriate. The rotated factor loading matrix permitted us to assess the congruence of the empirical data with theoretical expectations. The three identified clusters of items were about the same as those found by Pianta (2001), and the three factors could be labeled according to the original STRS structure: closeness, conflict, and dependency. Even the model fit indices were adequate according to the cut-off values proposed by various authors (Brown, 2006; Hu \& Bentler, 1995): $\chi^{2}(297, n=628)=741.16, p<.001$, RMSEA = .05, $\mathrm{CFI}=.96$, and SRMR $=.04$. However, 6 items were identified as deviations from the original. Five of them had a very low level of communality (<.30): items 4, 6, 12, 19, and 21. Item 25 cross-loaded on two different factors (factor loadings $>.40$ on conflict and dependency), and the higher factor loading was on the dependency factor and not on the conflict factor, as expected. Given this misbehavior and after having ascertained that the contents of the misbehaving items were not essential for the conceptual meaning of the factors, we decided to exclude these 6 items from the subsequent analysis (see Table 2).

\section{Table 2. Misbehaving items}

\begin{tabular}{ll}
\hline Item 4 & This child is uncomfortable with physical affection or touch from me \\
Item 6 & This child appears hurt or embarrassed when I correct him/her \\
Item 12 & This child tries to please me \\
Item 19 & When this child is misbehaving, he/she responds well to my look or tone of voice \\
Item 21 & I've noticed this child copying my behavior or ways of doing things \\
Item 25 & This child whines or cries when he/she wants something from me \\
\hline
\end{tabular}

Next, we recalculated the EFA on the 22 retained items and found that, on the basis of PA, the scree-plot examination (see Figure 1), and the interpretability criteria, the best solution was represented by the 3 -factor structure. The factor loadings, commonalities, fit indices, and correlations among the three factors are reported in Table 2. Another problematic item 
emerged (item 17: This child expresses hurt or jealousy when I spend time with other children). It was expected to load on the dependency subscale, but it was found to have a significant loading even on closeness factor. After carefully examining the content of the crossloading item, it was determined that it was fundamental for maintaining the meaning of the fact. It represented an aspect of the dependency factor that cannot be ignored. Again, the three extracted factors were labeled: (1) conflict, (2) closeness, and (3) dependency. This final model fit the data well: $\chi^{2}(168, n=628)=465.77, p<.001$, RMSEA $=.05, \mathrm{CFI}=.97$, and $\mathrm{SRMR}=.04$.

Table 3. Exploratory factor analysis (EFA) loadings for the items of the STRS

\begin{tabular}{|c|c|c|c|c|}
\hline \multirow[t]{2}{*}{ Item } & \multicolumn{3}{|c|}{ Factors } & \multirow[t]{2}{*}{$h^{2}$} \\
\hline & Conflict & Closeness & Dependency & \\
\hline Item 1 & -.29 & .66 & .16 & .69 \\
\hline Item 3 & -.02 & .61 & .25 & .54 \\
\hline Item 5 & -.13 & .71 & .13 & .64 \\
\hline Item 7 & .02 & .58 & -.05 & .31 \\
\hline Item 9 & .08 & .89 & -.27 & .68 \\
\hline Item 15 & -.32 & .64 & -.03 & .59 \\
\hline Item 27 & .00 & .93 & -.30 & .77 \\
\hline Item 28 & -.38 & .64 & .02 & .67 \\
\hline Item 2 & .81 & .00 & -.23 & .67 \\
\hline Item 11 & .82 & .14 & .07 & .67 \\
\hline Item 13 & .83 & -.01 & -.04 & .68 \\
\hline Item 16 & .78 & -.04 & -.06 & .62 \\
\hline Item 18 & .80 & .01 & .07 & .65 \\
\hline Item 20 & .87 & .00 & -.03 & .75 \\
\hline Item 22 & .88 & .10 & -.01 & .74 \\
\hline Item 23 & .75 & -.02 & .16 & .62 \\
\hline Item 24 & .83 & -.11 & -.12 & .73 \\
\hline Item 26 & .72 & -.21 & .06 & .63 \\
\hline Item 8 & .23 & .17 & .58 & .50 \\
\hline Item 10 & .22 & -.02 & .78 & .69 \\
\hline Item 14 & .38 & .00 & .52 & .46 \\
\hline Item 17 & .42 & .25 & .43 & .58 \\
\hline Factor correlations & 1 & 2 & 3 & \\
\hline 1. Conflict & - & -.23 & .33 & \\
\hline 2. Closeness & & - & .11 & \\
\hline 3. Dependency & & & - & \\
\hline
\end{tabular}




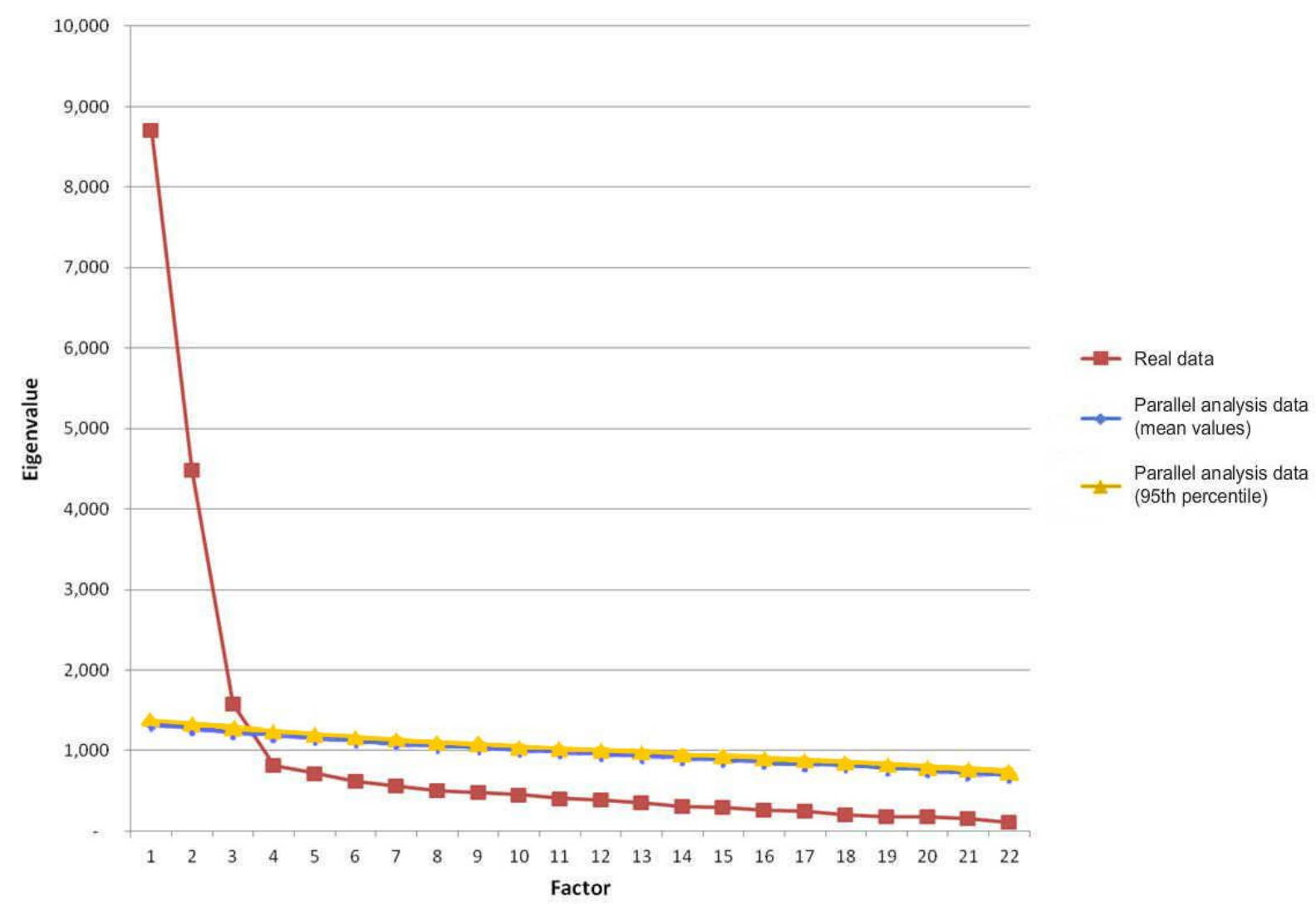

Figure 1. Exploratory factor analysis on STRS items: Screeplot and PA data

Confirmatory Factor Analysis

On the basis of the EFAs results, we conducted a CFA on the second half of the sample $(n=628)$. As with the EFA, the CFA was performed using WLSMV estimation and an oblique (Geomin) rotation. The tested factor structure is depicted in Figure 2. In the first step, we allowed the software to freely estimate covariances between the three factors. The data fit the model quite well $\left(\chi^{2}(206, n=628)=1126.54, p<.001\right.$, RMSEA $\left.=.084, \mathrm{CFI}=.93\right)$, and the freely estimated parameters were all significant except for the covariance between the closeness and dependency factors, which was not significantly different from 0 . The correlations between conflict and closeness and between conflict and dependency were both significant $(p<.01)$; they were equal to -.47 and .66 , respectively. To improve the parsimony and the fit of the model, we retested it after establishing the covariance between conflict and closeness as equal to 0 . The two nested models were then compared using the Mplus Difftest procedure, given that the simple Chi-square difference is impossible when using the WLSMV estimator. The difference was not significant $\left(\chi^{2}(1, n=628)=1.266, p=.26\right)$. Therefore the more parsimonious model was deemed preferable. Afterward, on the basis of the modification indices produced by Mplus, we allowed for the error terms between items 9 (This child spon- 
taneously shares information about himself/herself) and 27 (This child openly shares his/her feelings and experiences with me) to be correlated, given the similar phrasing of the two items (Brown, 2006). The fit of the final model was adequate: $\chi^{2}(206, n=628)=930.24, p<.001$, RMSEA $=.075$, and CFI $=.95$. The standardized factor loadings and factor covariances are reported in Table 3.

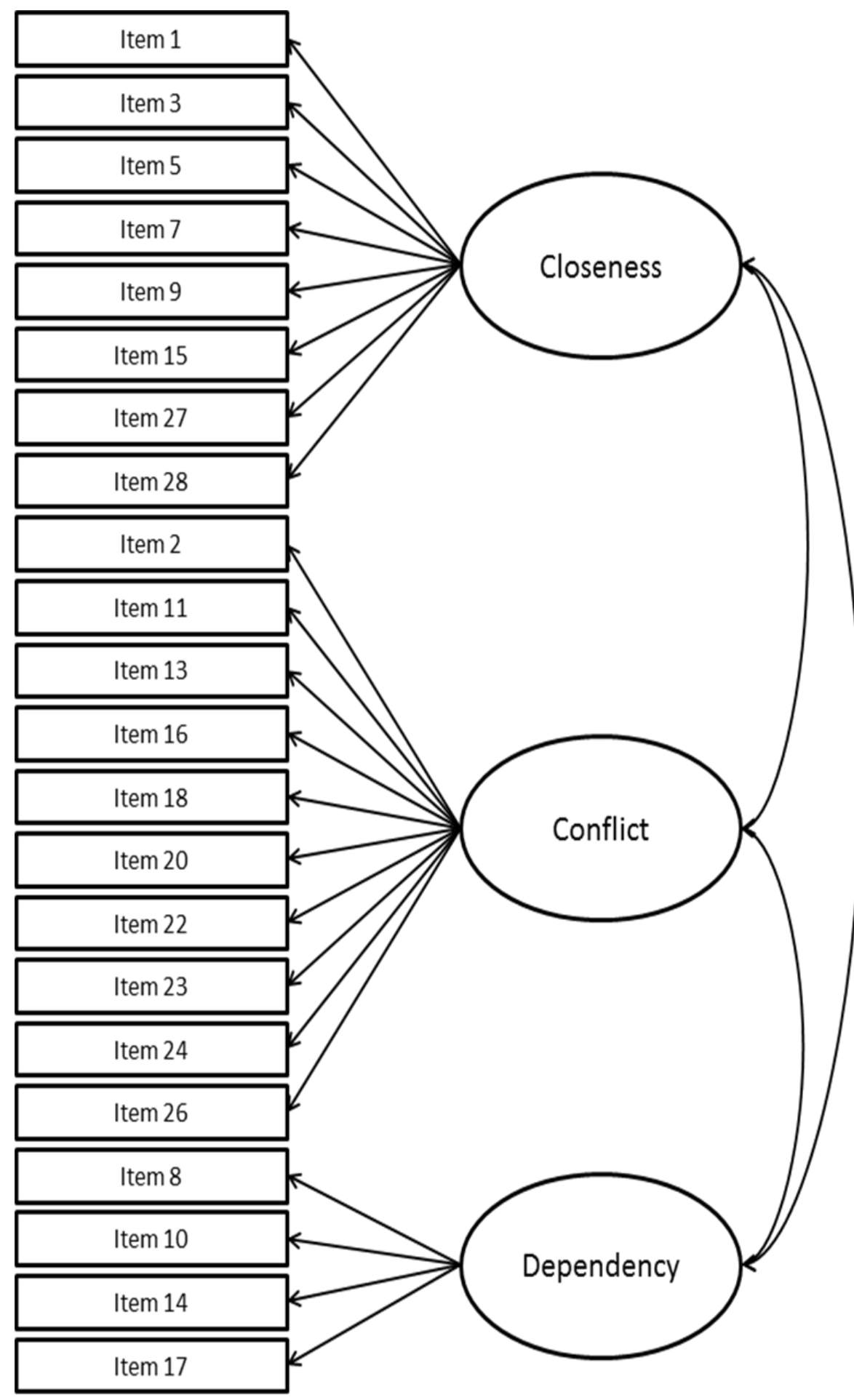

Figure 2. Tested STRS factor structure. 
Table 4. Results of confirmatory factor analysis (CFA) on STRS items: standardized loadings and factor correlations

\begin{tabular}{|c|c|c|c|}
\hline \multirow[t]{2}{*}{ Item } & \multicolumn{3}{|c|}{ Factors } \\
\hline & Conflict & Closeness & Dependency \\
\hline Item 1 & & .81 & \\
\hline Item 3 & & .54 & \\
\hline Item 5 & & .78 & \\
\hline Item 7 & & .51 & \\
\hline Item 9 & & .63 & \\
\hline Item 15 & & .81 & \\
\hline Item 27 & & .72 & \\
\hline Item 28 & & .87 & \\
\hline Item 2 & .81 & & \\
\hline Item 11 & .81 & & \\
\hline Item 13 & .82 & & \\
\hline Item 16 & .77 & & \\
\hline Item 18 & .75 & & \\
\hline Item 20 & .84 & & \\
\hline Item 22 & .82 & & \\
\hline Item 23 & .76 & & \\
\hline Item 24 & .91 & & \\
\hline Item 26 & .80 & & \\
\hline Item 8 & & & .54 \\
\hline Item 10 & & & .69 \\
\hline Item 14 & & & .71 \\
\hline Item 17 & & & .85 \\
\hline Factor & 1 & 2 & 3 \\
\hline 1. Conflict & - & -.49 & .58 \\
\hline 2. Closeness & & - & .00 \\
\hline 3. Dependency & 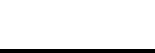 & 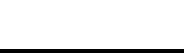 & - \\
\hline
\end{tabular}

\section{Reliability and Correlations between Subscales}

The three subscales resulting from the factor analyses (1. closeness, 8 items; 2 . conflict, 10 items; 3. dependency, 4 items) were analyzed to assess their internal consistency using Cronbach's alpha. The reliability coefficients were high for the closeness and conflict subscales and acceptable for dependency (see Table 5). This pattern is consistent with Pianta's (2001) results.

The correlations among the subscales were congruent with the CFA results, as the only two significant correlations were between closeness and conflict $(r(1254)=-.35, p<.001)$ 
and between dependency and conflict $(r(1254)=.50, p<.001)$, while closeness and dependency do not correlate significantly. The descriptive statistics, reliability coefficients, and correlations among the subscales are reported in Table 5.

Table 5. Internal consistency, scale means, standard deviations, and intercorrelations among STRS subscales $(\mathrm{n}=\mathbf{1 2 5 6})$

\begin{tabular}{lccccc}
\hline \multicolumn{1}{c}{ Scale } & $\alpha$ & Scale mean (SD) & 1 & 2 & 3 \\
\hline 1. Conflict (8 items) & .86 & $1.51(.73)$ & - & $-.35^{*}$ & $.50^{*}$ \\
2. Closeness (10 items) & .91 & $3.83(.68)$ & & - & .01 \\
3. Dependency (4 items) & .69 & $1.68(.78)$ & & & - \\
\hline$p<.01$ & & & & & \\
\hline
\end{tabular}

\section{Construct Validity of the STRS}

To investigate the construct validity of the STRS, we examined the associations of the three subscales with demographic subgroups, obtained by splitting the sample on the basis of sex and school grade. Afterward, we looked for evidence of criterion validity by computing the correlations of the subscale scores with academic achievement and commitment measures.

STRS across demographic subgroups. We employed one-way ANOVA to conduct comparisons on STRS scale scores across demographic subgroups defined by age and gender. With regard to age, we divided the sample into two different groups according to school grade (childhood school vs. primary school). We found significant differences between the two age subgroups for conflict $(F(1,1254)=71.65, \mathrm{p}<.001)$ and dependency $(F(1,1254)=86.12, p$ $<.001)$. The childhood school pupils showed significantly higher means both on the conflict and dependency subscales (see Table 5).

With reference to sex, females showed lower levels of conflict $(F(1,1254)=14.78, p$ $<.001)$, higher levels of closeness $(F(1,1254)=16.78, p<.001)$, and higher levels of dependency $(F(1,1254)=4.88, p=.027)($ see Table 6$)$. 
Table 6. Means and standard deviations across school grade and gender subgroups

\begin{tabular}{lcccc}
\hline & \multicolumn{2}{c}{ School } & & \\
\cline { 2 - 5 } & Childhood & Primary & Male & Female \\
\hline \multicolumn{1}{c}{ Scale } & $\mathrm{M}(\mathrm{SD})$ & $\mathrm{M}(\mathrm{SD})$ & $\mathrm{M}(\mathrm{SD})$ & $\mathrm{M}(\mathrm{SD})$ \\
& & & & \\
\hline Conflict & $1.70(.84)$ & $1.36(.60)$ & $1.59(.80)$ & $1.43(.66)$ \\
Closeness & $3.84(.71)$ & $3.83(.66)$ & $3.76(.71)$ & $3.91(.65)$ \\
Dependency & $1.90(.89)$ & $1.50(.63)$ & $1.63(.75)$ & $1.73(.81)$ \\
\hline
\end{tabular}

Correlations with academic achievement and commitment. As further evidence of the construct validity, we computed bivariate correlations among the three subscale scores and academic achievement and commitment measures. The following table depicts the correlations. All the computed correlations are significant $(p<.05)$, and they follow a pattern expected on the basis of the theoretical considerations.

Table 7. Intercorrelations among the STRS subscales and academic achievement and commitment $(\mathrm{N}=1256)$

\begin{tabular}{lcc}
\hline Scale & $\begin{array}{c}\text { Academic } \\
\text { achievement }\end{array}$ & Commitment \\
\hline 1. Conflict & -.25 & -.34 \\
2. Closeness & .32 & .40 \\
3. Dependency & -.20 & -.17 \\
\hline
\end{tabular}

Note: All the correlations are significant: $p<.01$

\section{Discussion}

The 22-item Italian version of the scale confirms the 3-factors structure suggested by Pianta (2001) and underlines the essential dimensions of proximity, conflict, and dependency. Stepping back from the original version, we decided to focus on the correlation between dimensions, particularly within their relation to factors. Some items have been removed because they were deemed alien to the southern European context in which the investigation was con- 
ducted. It is context that is unified by the organization of the didactic settings and by the interpretation of given behaviors related to the teacher-pupil relationship (Gregoriadis \& Tsigilis, 2008; Moreno García \& Martínez-Arias, 2008).

In the Greek adaptation of this work, item 6, already excluded from some studies carried out in Belgium and North America, registered low communality. It must be noted that item 6 was also removed from the Spanish adaptation of the questionnaire. The same can be said for items 21 and 25. In the Italian version, items 4, 12, and 19 were also excluded from the questionnaire. Nevertheless, the instrument presents a high level of reliability when all other subscales are involved.

Some very interesting patterns related to the value of the instrument's different dimensions were registered in Italy, such as the type of school and the child's gender. The diminishing of the conflict and dependency subscales during the transition between kindergarten and primary school probably originated from the natural cognitive, emotional, and social development of the children. In this developmental time of life, we observe an increase in autonomy, self-control, emotional self-regulation, and conflict management skills.

Besides the changes ascribed to the relational, emotive, and cognitive dimensions (Bredekamp \& Copple, 1997; Pianta \& Kraft-Sayre, 1999), other changes depend on the differences in organization between the two types of schools. In preschool, for instance, teachers tend to spend more time in direct contact with pupils, a fact that, apparently, increases the perception of the conflict dimension in both teachers and pupils (Early Child Care Research Network [NICHD], 2005). This reality could explain the higher incidence of conflict in the creation and development of relationships during preschool.

The differences related to the pupils' gender in the Italian sample are, in fact, similar to other instances found in international literature on the subject. Teachers perceive a higher sense of closeness with girls and more conflicts with boys (Birch \& Ladd, 1997, Hamre \& Pianta, 2001; Hamre, Pianta, Downer, \& Mashburn, 2008; Hughes \& Kwok, 2007; Gregoriadis \& Tsigilis, 2008; Moreno García \& Martínez-Arias, 2008). The higher level of dependency found in the relationship with girl pupils is consistent with studies carried out in other European countries (Gregoriadis \& Tsigilis, 2008; Moreno García \& Martínez-Arias, 2008), but it is inconsistent with those conducted in the U.S., which do not record such a dif- 
ference. The common elements among the studies conducted in southern European countries seem to suggest shared cultural traits that will become the object of future research. As for the Italian cultural context, the local literature emphasizes a prominent difference in the thrust toward autonomy among genders (Ruspini, 2009; Saraceno, 2003; Saraceno \& Naldini, 2007).

As for proficiency and commitment, we observed significant correlations with the perception of the relationship quality, in agreement with international studies (Birch \& Ladd, 1997; Hughes et al., 2005; Fumoto et al., 2007; Graziano et al., 2007; Moreno García \& Martínez-Arias, 2008; Pianta \& Stuhlman, 2004; Rey et al., 2007); more specifically, high levels of closeness and low levels of conflict and dependency turn out to be correlated to high school proficiency.

\section{Limitations}

The teacher-pupil relationship should be described under the perspective of systemic analysis and of bidirectional influence (Bronfenbrenner \& Morris, 2006). However, in this study, only the perception of the teacher's relational capacities are investigated for two reasons. First, this research study's primary goal was to validate the STRS in the Italian context. Second, in our country, we lack instruments that are suitable to evaluate the child's point of view and are derived from international literature and standardized for the Italian context; therefore, so far, it has not been possible to investigate the child's point of view in a reliable and valid way.

This research project is a little lacking with respect to the predictive and concurrent validity. More specifically, it would be important to also investigate the child's present and future scholastic abilities, temperamental traits, behavioral problems, emotional and social capabilities, and peer relationships; similarly, it would be important to take into account variables regarding the teachers, such as their prior professional experience, personality features, relational capacities, self-efficacy perception, and perceived stress level.

Following the construct validation presented here, this research study addresses characteristics of the instrument's validity that have not been yet investigated, particularly the predictive validity of the measure when it is used in longitudinal studies on school success and adaptability to an educational context. 


\section{Conclusions}

This study contributes to the widening of the international literature concerning the teacher-pupil relationship under different perspectives: cross-cultural, statistical, and applicative. This work strengthens the psychometric basis of the STRS by confirming the threedimensional structure of the original instrument. Therefore, on the basis of the CFA, the instrument proves to be applicable also to the Italian context.

The teacher-pupil relationship is important, particularly in early childhood (Palermo, Hanish, Martin, Fabes, \& Reiser, 2007) and, in general, because of its effects on the child's psychological well-being and social adaptation (Birch \& Ladd, 1997; Baker, Grant, \& Morlock, 2008; Koomen et al., 2012); for this reason, it is fundamental to have available an instrument that can be used to assess the relationship itself. The STRS, given its validity, can be a serviceable questionnaire for studying such a construct, both as a monitoring scale of a given relationship and as a way to help teachers achieve a better level of awareness of their educational skills. As already noted while presenting the multidimensional construct, the three dimensions affect distinct aspects of the child development; it follows that the STRS can provide teachers with useful indications for better regulating their own educational practice.

\section{References}

Ainsworth, M. S., Blehar, M. C., Waters, E., \& Wall, S. (1978). Patterns of attachment: A psychological study of the Strange Situation. Hillsdale, NJ: Erlbaum.

Amidon, E., \& Hunter, E. (1967). Improving teaching: The analysis of classroom verbal interaction. New York, NY: Holt, Rinehart \& Winston.

Baker, J. A. (2006). Contributions of teacher-child relationships to positive school adjustment during elementary school. Journal of School Psychology, 44(3), 211-229. doi:10.1016/j.jsp.2006.02.002

Baker, J. A., Grant, S., \& Morlock, L. (2008). The teacher-student relationship as a developmental context for children with internalizing or externalizing behavior problems. School Psychology Quarterly, 23, 3-15. doi:10.1037/1045-3830.23.1.3

Barnett, W. S., \& Yarosz, D. (2004). Who goes to preschool and why does it matter? Preschool Policy Matters, Issue 8. New Brunswick, NJ: NIEER. 
Birch, S. H., \& Ladd, G. W. (1997). The teacher-child relationship and children's early school adjustment. Journal of School Psychology, 35(1),61-79. doi:10.1016/S00224405(96)00029-5

Birch, S. H., \& Ladd, G. W. (1998). Children's interpersonal behaviors and the teacher-child relationship. Developmental Psychology, 34(5), 934-946. doi:10.1037/00121649.34.5.934

Bredekamp, S., \& Copple, C. (Eds.) (1997). Developmentally appropriate practices in early childhood programs (Rev. Ed.). Washington, DC: NAEYC.

Bronfenbrenner, U. (1977). Toward an experimental ecology of human development. American Psychologist, 32(7), 513-531. doi:10.1037/0003-066X.32.7.513

Bronfenbrenner, U., \& Morris, P. A. (2006). The bioecological model of human development. In R. M. Lerner (Ed.), Handbook of child psychology (Vol. 1): Theoretical models of human development (6th ed., pp. 793-828). Hoboken, NJ: Wiley.

Brown, T. A. (2006). Confirmatory factor analysis for applied research. New York, NY: The Guilford Press.

Burchinal, M. R., Cryer, D., Clifford, R., \& Howes, C. (2002). Caregiver training and classroom quality in child care centers. Applied Developmental Science, 6(1), 2-11. doi:10.1207/S1532480XADS0601_01

Burchinal, M., Howes, C., Pianta, R., Bryant, D., Early, D., Clifford, R., \& Barbarin, O. (2008). Predicting child outcomes at the end of kindergarten from the quality of prekindergarten teacher-child interactions and instruction. Applied Developmental Science, 12(3), 140-153. doi:10.1080/10888690802199418

Burchinal, M. R., Peisner-Feinberg, E., Pianta, R. C., \& Howes, C. (2002). Development of academic skills from preschool through second grade: Family and classroom predictors of developmental trajectories. Journal of School Psychology, 40(5), 415-436. doi:10.1016/S0022-4405(02)00107-3

Buyse, E., Verschueren, K., Doumen, S., Van Damme, J., \& Maes, F. (2008). Classroom problem behavior and teacher-child relationships in kindergarten: The moderating role of classroom climate. Journal of School Psychology, 46(4), 367-391. doi:10.1016/j.jsp.2007.06.009

Cattell, R. B. (1966). Handbook of multivariate experimental psychology. Chicago, IL: Rand McNally. 
Cicchetti, D., \& Lynch, M. (1993). Toward an ecological/transactional model of community violence and child maltreatment: Consequences for children's development. Psychiatry, 56(1), 96-118.

Davis, H. A. (2003). Conceptualizing the role and influence of student-teacher relationships on children's social and cognitive development. Educational Psychologist, 38(4), $207-$ 234. doi:10.1207/S15326985EP3804_2

Decker, D. M., Dona, D. P., \& Christenson, S. L. (2007). Behaviorally at-risk African American students: The importance of student-teacher relationships for student outcomes. Journal of School Psychology, 45(1), 83-109. doi:10.1016/j.jsp.2006.09.004

DiLalla, L. F., Marcus, J. L., \& Wright-Phillips, M. (2004). Longitudinal effects of preschool behavioral styles on early adolescent school performance. Journal of School Psychology, 42(5), 385-401. doi:10.1016/j.jsp.2004.05.002

Doumen, S., Verschueren, K., Buyse, E., Germeijs, V., Luyckx, K., \& Soenens, B. (2008). Reciprocal relations between teacher-child conflict and aggressive behavior in kindergarten: A three-wave longitudinal study. Journal of Clinical Child and Adolescent Psychology, 37(3), 588-599. doi:10.1080/15374410802148079

Early Child Care Research Network [NICHD]. (2005). Early child care and children's development in the primary grades: Follow-up results from the NICHD study of early child care. American Educational Research Journal, 42(3), 537-570. doi:10.3102/00028312042003537

Ewing, A. R., \& Taylor, A. R. (2009). The role of child gender and ethnicity in teacher-child relationship quality and children's behavioral adjustment in preschool. Early Childhood Research Quarterly, 24(1), 92-105. doi:10.1016/j.ecresq.2008.09.002

Fondazione G. Agnelli (2011). Rapporto sulla scuola in Italia 2011. Roma-Bari, Italia: Laterza.

Fumoto, H., Hargreaves, D. J., \& Maxwell, S. (2007). Teachers' perceptions of their relationships with children who speak English as an additional language in early childhood settings. Journal of Early Childhood Research, 5(2), 135-153. doi:10.1177/1476718X07076680

Graziano, P. A, Reavis, R. D., Keane, S. P., \& Calkins, S. D. (2007). The role of emotion regulation and children's early academic success. Journal of School Psychology, 45(1), 319. doi:10.1016/j.jsp.2006.09.002 
Gregoriadis, A., \& Tsigilis, N. (2008). Applicability of the Student-Teacher Relationship Scale (STRS) in the Greek educational setting. Journal of Psychoeducational Assessment, 26(2), 108-120. doi:10.1177/0734282907306894

Hamre, B. K., \& Pianta, R. C. (2001). Early teacher-child relationships and the trajectory of children's school outcomes through eighth grade. Child Development, 72(2), 625-638. doi:10.1111/1467-8624.00301

Hamre, B. K., \& Pianta, R. C. (2007). Learning opportunities in preschool and early elementary classrooms. In R. Pianta, M. Cox, \& K. Snow (Eds.), School readiness and the transition to kindergarten in the era of accountability (pp. 49-84). Baltimore: Brookes Publishing.

Hamre, B. K., \& Pianta, R. C. (2010). Classroom environments and developmental processes: conceptualization \& measurement. In J. Meece \& J. Eccles (Eds.). Handbook of research on schools, schooling, and human development (pp 25-41). New York: Routledge.

Hamre, B. K., Pianta, R. C., Downer, J. T., \& Mashburn, A. J. (2008). Teachers' perceptions of conflict with young students: Looking beyond problem behaviors. Social Development, 17(1), 115-136. doi:10.1111/j.1467-9507.2007.00418.x

Horn, J. L. (1965). A rationale and test for the number of factors in factor analysis. Psychometrika, 30, 179-185.

Howes, C. (1999). Attachment relationships in the context of multiple caregivers. In J. Cassidy \& P. R. Shaver (Eds.), Handbook of attachment: Theory, research, and clinical applications (pp. 671-687). New York, NY: Guilford.

Howes, C. (2000). Social-emotional classroom climate in child care, child-teacher relationships and children's second grade peer relations. Social Development, 9(2), 191-204. doi:10.1111/1467-9507.00119

Howes, C., \& Hamilton, C. E. (1992). Children's relationships with child care teachers: Stability and concordance with parental attachments. Child Development, 63(4), 867-878. doi:10.1111/j.1467-8624.1992.tb01667.x

Howes, C., \& Ritchie, S.H. (1999). Attachment organizations in children with difficult life circumstances. Development and Psychopathology, 11(2), 251-268. doi:10.1017/S0954579499002047 
Hoyle, R. H., \& Duvall, J. L. (2004). Determining the number of factors in exploratory and confirmatory factor analysis. In D. Kaplan (Ed.), The Sage Handbook of Quantitative Methodology for Social Sciences (pp. 301-315). Thousand Oaks, CA: Sage.

Hu, L. T., \& Bentler, P. (1995). Evaluating model fit. In R. H. Hoyle (Ed.), Structural equation modeling. Concepts, issues, and applications (pp. 76-99). London, UK: Sage.

Hughes, J. N., Cavell, T. A., \& Jackson, T. (1999). Influence of the teacher-child relationship on childhood conduct problems: A prospective study. Journal of Clinical Child Psychology, 28(2), 173-184. doi:10.1207/s15374424jccp2802_5

Hughes, J. N., Gleason, K. A, \& Zhang, D. (2005). Relationship influences on teachers' perceptions of academic competence in academically at-risk minority and majority first grade students. Journal of school psychology, 43(4), 303-320. doi:10.1016/j.jsp.2005.07.001

Hughes, J., \& Kwok, O. M. (2007). Influence of student-teacher and parent-teacher relationships on lower achieving readers'engagement and achievement in the primary grades. Journal of Educational Psychology, 99(1), 39-51. doi:10.1037/0022-0663.99.1.39

Hughes, J. N., Luo, W., Kwok, O. M., \& Loyd, L. K. (2008). Teacher-student support, effortful engagement, and achievement: A 3-year longitudinal study. Journal of Educational Psychology, 100(1), 1-14. doi:10.1037/0022-0663.100.1.1

Jerome, E. M., Hamre, B. K., \& Pianta, R. C. (2009). Teacher-child relationships from kindergarten to sixth grade: Early childhood predictors of teacher-perceived conflict and closeness. Social Development, 18(4), 915-945. doi:10.1111/j.14679507.2008.00508.x

Kesner, J. E. (2000). Teacher characteristics and the quality of child-teacher relationships. Journalof School Psychology, 38(2), 133-149. doi:10.1016/S0022-4405(99)00043-6

Klauer, K. J. (1985). Framework for a theory of teaching. Teaching and teacher education, 1(1), 5-17. doi:10.1016/0742-051X(85)90026-57

Koomen, H. M. Y., Verschueren, K., van Schooten, E., Jak, S., \& Pianta, R. C. (2012). Validating the Student-Teacher Relationship Scale: Testing factor structure and measurement invariance across child gender and age in a Dutch sample. Journal of School Psychology, 50, 215-234. doi:10.1016/j.jsp.2011.09.001

Ladd, G. W., Birch, S. H., \& Buhs, E. S. (1999). Children's social and scholastic lives in kindergarten: Related spheres of influence? Child Development, 70(6), 1373-1400. doi:10.1111/1467-8624.00101 
Loevinger, J. (1957). Objective tests as instruments of psychological theory. Psychological Reports, 3(9), 635-694. doi:10.2466/PR0.3.7.635-694

Lynch, M., \& Cicchetti, D. (1992). Maltreated children's reports of relatedness to their teachers. In R. C. Pianta (Ed.), Beyond the parent: The role of other adults in children's lives. Newdirections for child development, Vol. 57 (pp. 81-107). San Francisco, CA: Jossey-Bass.

Mantzicopoulos, P. (2005). Conflictual relationships between kindergarten children and their teachers: Associations with child and classroom context variables. Journal of School Psychology, 43(5), 425-442. doi:10.1016/j.jsp.2005.09.004

Mashburn, A. J., Downer, J. T., Hamre, B. K., Justice, L. M., \& Pianta, R. C. (2010). Consultation for teachers and children's language and literacy development during prekindergarten. Applied Developmental Science, 14, 179-196. doi:10.1080/10888691.2010.516187

Mashburn, A. J., Hamre, B. K., Downer, J. T., \& Pianta, R. C. (2006). Teacher and classroom characteristics associated with teachers' ratings of prekindergartners' relationships and behaviors. Journal of Psychoeducational Assessment, 24(4), 367-380. doi:10.1177/0734282906290594

Ministero della Pubblica Istruzione. (2007). Indicazioni per il Curricolo per la scuola dell'infanzia e per il primo ciclo di istruzione. Roma, Italia: Miur.

Moreno-García, R., \& Martínez- Arias, R. (2008). Adaptación española de la escala de relación profesor-alumno (STRS) de Pianta. Psicología de la Educación, 14(1), 11-27

Murray, C., Murray, K. M., \& Waas, G. A. (2008). Child and teacher reports of teacherstudent relationships: Concordance of perspectives and associations with school adjustment in urban kindergarten classrooms. Journal of Applied Developmental Psychology, 29(1),49-61. doi:10.1016/j.appdev.2007.10.006

Muthén, B. O., \& Kaplan D. (1985). A comparison of some methodologies for the factor analysis of non-normal Likert variables. British Journal of Mathematical and Statistical Psychology, 38, 171-189.

Muthén, L. K., \& Muthén, B. O. (2007). Mplus user's guide. Los Angeles, CA: Muthén \& Muthén.

Myers, S. S., \& Pianta, R. C. (2008). Developmental commentary: Individual and contextual influences on student-teacher relationships and children's early problem behaviors. Journal of Clinical Child \& Adolescent Psychology, 37(3), 600-608. doi:10.1080/15374410802148160 
O'Connor, B. P. (2000). SPSS and SAS programs for determining the number of components using parallel analysis and Velicer's MAP test. Behavior Research Methods, Instruments and Computers, 32(3), 396-402. doi:10.3758/BF03200807

O’Connor, E., \& McCartney, K. (2006). Testing associations between young children's relationships with mothers and teachers. Journal of Educational Psychology, 98(1), 87-98. doi:10.1037/0022-0663.98.1.87

O’Connor, E., \& McCartney, K. (2007). Examining teacher-child relationships and achievement as part of an ecological model of development. American Educational Research Journal, 44(2), 340-369. doi:10.3102/0002831207302172

Organization for Economic Co-operation and Development [OECD] (2011). Education at a glance 2011: Highlights. Paris, France: OECD Publishing. doi:10.1787/eag_highlights-2011-en

Palermo, F., Hanish, L. D., Martin, C. L., Fabes, R. A., \& Reiser, M. (2007). Preschoolers' academic readiness: What role does the teacher-child relationship play? Early Childhood Research Quarterly, 22(4), 407-422. doi:10.1016/j.ecresq.2007.04.002

Pianta, R. C. (1994). Patterns of relationship between children and kindergarten teachers. Journal of School Psychology, 32(1), 15-31. doi:10.1016/0022-4405(94)90026-4

Pianta, R. C. (1999). Enhancing relationships between children and teachers. Washington, DC: American Psychological Association.

Pianta, R. C. (2001). Student-Teacher Relationship Scale: Professional manual. Odessa, FL: Psychological Assessment Resources, Inc.

Pianta, R. C., Hamre, B., \& Stuhlman, M. (2003). Relationships between teachers and children. In W. M. Reynolds, G. E. Miller, \& I. B. Weiner (Eds.), Handbook of psychology: Volume7 Educational psychology (pp. 199-234). Hoboken, NJ: Wiley.

Pianta, R. C., \& Kraft-Sayre, M. E. (1999). Parents' observations about their children's transitions to kindergarten. Young Children, 54(3), 47-51.

Pianta, R., Mashburn, A., Downer, J., Hamre, B., \& Justice, L. (2008). Effects of webmediated professional development resources on teacher-child interactions in prekindergarten classrooms. Early Childhood Research Quarterly, 23, 431-451. doi:10.1016/j.ecresq.2008.02.001

Pianta, R. C., Nimetz, S. L., \& Bennett, E. (1997). Mother-child relationships, teacher-child relationships, and school outcomes in preschool and kindergarten. Early Childhood Research Quarterly, 12(3), 263-280. doi:10.1016/S0885-2006(97)90003-X 
Pianta, R. C., \& Steinberg, M. (1992). Teacher-child relationships and the process of adjusting to school. In R. C. Pianta (Ed.), Beyond the parent: The role of other adults in children's lives. New directions for child development, Vol. 57 (pp. 81-107). San Francisco, CA: Jossey-Bass.

Pianta, R. C., Steinberg, M. S., \& Rollins, K. B. (1995). The first two years of school: Teacher-child relationships and deflections in children's classroom adjustment. Development and Psychopathology, 7(2), 295-312. doi:10.1017/S0954579400006519

Pianta, R. C., \& Stuhlman, M. W. (2004). Teacher-child relationship and children's success in the first years of school. School Psychology Review, 33(3), 444-458.

Pianta, R. C., \& Walsh, D. J. (1996). High-risk children in schools: Constructing sustaining relationships. New York, NY: Routledge.

Rey, R. B., Smith, A. L., Yoon, J., Somers, C., \& Barnett, D. (2007). Relationships between teachers and urban African American children: The role of informant. School Psychology International, 28(3), 346-364. doi:10.1177/0143034307078545

Rudasill, K. M., Rimm-Kaufman, S., Justice, L., \& Pence, K. (2006). Temperament and language skills as predictors of teacher-child relationship quality in preschool. Early Education and Development, 17(2), 271-291.doi:10.1207/s15566935eed1702_4

Ruspini, E. (2009). Le identità di genere. Roma, Italia: Carocci.

Russell, D. W. (2002). In search of underlying dimensions: The use (and abuse) of factor analysis in PSPB. Personality and Social Psychology Bulletin, 28(12), 1629-1646. doi:10.1177/014616702237645

Saft, E. W. (1994). A descriptive study of the Student-Teacher Relationship Scale used with preschoolers. (Unpublished doctoral dissertation). University of Virginia, Charlottesville, VA.

Saft, E. W., \& Pianta, R. C. (2001). Teacher's perceptions of their relationships with students: Effects of child age, gender, and ethnicity of teachers and children. School Psychology Quarterly, 16(2), 125-141. doi:10.1521/scpq.16.2.125.18698

Saraceno, C. (2003). Mutamenti della famiglia e politiche sociali in Italia. Bologna, Italia: Il Mulino.

Saraceno, C., \& Naldini, M. (2007). Sociologia della famiglia. Bologna, Italia: Il Mulino.

Silver, R. B., Measelle, J. R., Armstrong, J. M., \& Essex, M. J. (2005). Trajectories of classroom externalizing behavior: Contributions of child characteristics, family characteristics, and the teacher-child relationship during the school transition. Journal of School Psychology, 43(1), 39-60. doi:10.1016/j.jsp.2004.11.003 
Snow, K. L. (2006). Measuring school readiness: Conceptual and practical considerations. Early Education and Development, 17(1), 7-41.doi:10.1207/s15566935eed1701_2

Steinberg, M. S. (1993). Teacher-student relationships and children's adjustment to kindergarten and first grade. (Unpublished doctoral dissertation). University of Virginia, Charlottesville, VA.

Stuhlman, M. W., \& Pianta, R. C. (2002). Teachers' narratives about their relationships with children: Associations with behavior in classrooms. School Psychology Review, 31(2), 148-163.

Tsigilis N., \& Gregoriadis, A. (2008). Measuring teacher-child relationships in the Greek kindergarten setting: A validity study of the Student-Teacher Relationship ScaleShort Form. Early Education \& Development, 19(5), 816-835. doi:10.1080/10409280801975826

Tudge, J. R. H., Mokrova, I., Hatfield, B. E., \& Karnik, R. B. (2009). Uses and misuses of Bronfenbrenner'sbioecological theory of human development. Journal of Family Theory and Review, 1(4), 198-210. doi:10.1111/j.1756-2589.2009.00026.x

Van de Vijver, F. J. R., \& Hambleton, R. K. (1996). Translating tests: Some practical guidelines. European Psychologist, 1(2), 89-99. doi:10.1027/1016-9040.1.2.89

Waters, E., \& Deane, K. E. (1985). Defining and assessing individual differences in attachment relationships: Q-methodology and the organization of behavior in infancy and early childhood. In I. Bretherton, \& E. Waters (Eds.), Growing points of attachment theory and research. Monographs of the Society for Research in Child Development, 50 (1-2, Serial No. 209) (pp. 41-65).

Webb, M. L., \& Neuharth-Pritchett, S. (2011). Examining factorial validity and measurement invariance of the Student-Teacher Relationship Scale. Early Childhood Research Quarterly, 26(2), 205-215. doi:10.1016/j.ecresq.2010.09.004 
Michela Fraire et al.

[This page intentionally left blank] 